\title{
Penentuan Klasifikasi Tanah Sistem Uscs (Unified Soil Classification System) dengan Bantuan Ms Excel
}

\author{
Bertha Cahya Carolin ${ }^{1}$, Suhendra ${ }^{2}$, Wari Dony ${ }^{3}$ \\ ${ }^{1}$ Program Studi Teknik Sipil, Fakultas Teknik, Universitas Batanghari \\ 2, Jurusan Teknik Sipil, Fakultas Teknik, Universitas Batanghari \\ Correspondence email: suhendra_domas@yahoo.com
}

\begin{abstract}
Abstrak. Klasifikasi tanah sistem unified (USCS) dilakukan utamanya menggunakan data distribusi butiran dan kadar air batas cair serta kadar air batas plastis. Proses penentuan klasifikasi cukup memakan waktu, jika dilakukan secara manual. Penelitian ini dimaksudkan untuk memudahkan pengklasifikasian tanah dengan memanfaatkan Visual Basic Application (VBA) yang ada di Ms. Excel. Hasil penelitian menunjukkan bahwa dengan menentukan format hasil uji distribusi butir dan batas atterberg, aplikasi yang dibuat dengan segera bisa mengklasifikasikan tanah. Aplikasi yang dibuat bisa menganalisis semua klasifikasi tanah sesuai dengan klasifikasi sistem unified.
\end{abstract}

Kata Kunci : batas atterberg 1, analisis saringan 2, sistem unified (USCS) 3, Ms.Excel VBA 4.

\section{PENDAHULUAN}

Tanah merupakan material yang terdiri dari himpunan butiran mineral-mineral, bahan organik, dan endapanendapan yang relatif lepas, yang terletak di atas batuan dasar. Diantara ruang partikel-partikel terdapat zat cair dan gas yang mengisi ruang-ruang kosong tersebut. Ukuran partikel tanah dapat bervariasi dan sifat fisik dari tanah kebanyakan bergantung dari faktor ukuran, bentuk, serta kandungan kimia dari partikel tersebut (Hardiyatmo, 2012). Tanah sebagai tempat berdirinya suatu konstruksi harus mampu menahan beban yang ada diatasnya karena tanah merupakan landasan untuk menerima dan menahan beban. Sistem klasifikasi tanah dibuat untuk menentukan kesesuaian terhadap pemakaian tertentu serta untuk menginformasikan tentang keadaan tanah dari suatu daerah kepada daerah lainnya dalam bentuk berupa data dasar. Klasifikasi tanah juga berguna untuk studi yang lebih terperinci mengenai keadaan tanah tersebut serta kebutuhan akan pengujian untuk menentukan sifat teknis tanah seperti karakteristik pemadatan, kekuatan tanah, berat isi, dan sebagainya (Bowles, 1991). Microsoft excel adalah sebuah program aplikasi yang berfungsi untuk mengolah angka menggunakan spreadsheet yang terdiri dari baris dan kolom untuk menjalankan perintah serta melakukan fungsi excel yang dikenal sebagai formula excel (Wicaksono, 2002). Ms. Excel ialah program pengolah angka yang paling cepat dan praktis, program ini juga mampu menghasilkan hasil yang maksimal, tinggal bagaimana memanfaatkan fasilitas-fasilitas yang ada sebaik mungkin. Seperti, bahasa pemrograman visual basic application (VBA) yang juga dapat digunakan untuk aplikasi perhitungan. VBA (Visual Basic Application) adalah bahasa fungsi dan perintah program dimiliki Microsoft office yang disimpan dalam bahasa Visual Basic yaitu sebuah bahasa pemrograman untuk membuat program perangkat lunak (Winarno, 2014). Dalam menentukan klasifikasi tanah terdapat beberapa parameter tanah dibutuhkan dari beberapa uji laboratorium yang berada pada kelompok uji indeks propertis, antara lain : 1. Batas atterberg; 2. Analisis saringan. Akan tetapi dari beberapa literatur berupa tabel dan rumus yang digunakan ada banyak, sehingga dalam pengambilan keputusan mengenai suatu jenis tanah cukup memakan waktu.

Berdasarkan latar belakang, maka rumusan masalah pada penelitian ini adalah:

1. Bagaimana cara menentukan klasifikasi tanah secara manual dengan pengolahan data pengujian sifat fisik tanah ?

2. Bagaimana memanfaatkan fungsi yang ada pada Ms. Excel VBA dalam menentukan klasifikasi tanah ?

Tujuan pada penelitian ini yaitu:

1. Untuk menentukan klasifikasi tanah secara manual dengan pengolahan data pengujian sifat fisik tanah.

2. Untuk memanfaatkan fungsi yang ada pada Ms. Excel VBA dalam menentukan klasifikasi tanah

\section{METODE}

Metode Penelitian merupakan strategi umum yang dianut dalam pengumpulan dan analisis data yang diperlukan guna menjawab persoalan yang dihadapi. (Furchan, 2004). Penelitian ini mengambil sumber dari jurnal-jurnal dan segala referensi yang mendukung guna kebutuhan penelitian. Sumber yang diambil adalah sumber yang berkaitan dengan klasifikasi tanah metode Unified Soil Classification System (USCS). Sedangkan untuk studi literatur aplikasi yang digunakan berasal buku tata cara penggunaan software Ms. Excel 2010.

Data merupakan segala fakta dan angka yang dapat dijadikan bahan untuk menyusun suatu informasi, sedangkan informasi adalah hasil pengolahan data yang dipakai untuk suatu keperluan (Arikunto, 2002). Data yang 
diperlukan dalam penelitian ini, yaitu data sekunder yang berupa hasil pengujian sifat fisik tanah, diperoleh dari laporan pengujian sampel tanah Undisturbed di Laboratorium Fakultas Teknik Universitas Batanghari.

Setelah diperoleh data hasil pengujian batas konsistensi dari tanah yaitu batas cair (liquid limit) dan batas plastis (plastic limit) dan dilakukan pengujian analisis ukuran butiran tanah maka nilai dari hasil pengujian tersebut diolah dengan bantuan Ms. Excel.

Hasil data yang diperoleh kemudian ditampilkan dalam bentuk tabel dan dibuat grafik.

Dari rangkaian pengujian yang dilaksanakan di laboratorium, maka :

1. Dari pengujian batas-batas atterberg, diperoleh nilai batas cair (liquid limit), batas plastis (plastic limit), dan Indek plastisitas (plastis indeks) yang digunakan untuk mengklasifikasikan tanah.

2. Dari pengujian analisis saringan (sieve analysis), diperoleh pembagian ukuran butiran tanah, yang akan digunakan untuk mengklasifikasikan tanah.

Dalam melakukan penelitian ini, terdapat langkah-langkah yang diambil untuk mendukung proses penelitian yang akan dibuat agar penelitian ini dapat berjalan lebih terarah dan sistematis. Adapun bagan alir pada penelitian ini dapat dilihat pada gambar 1.

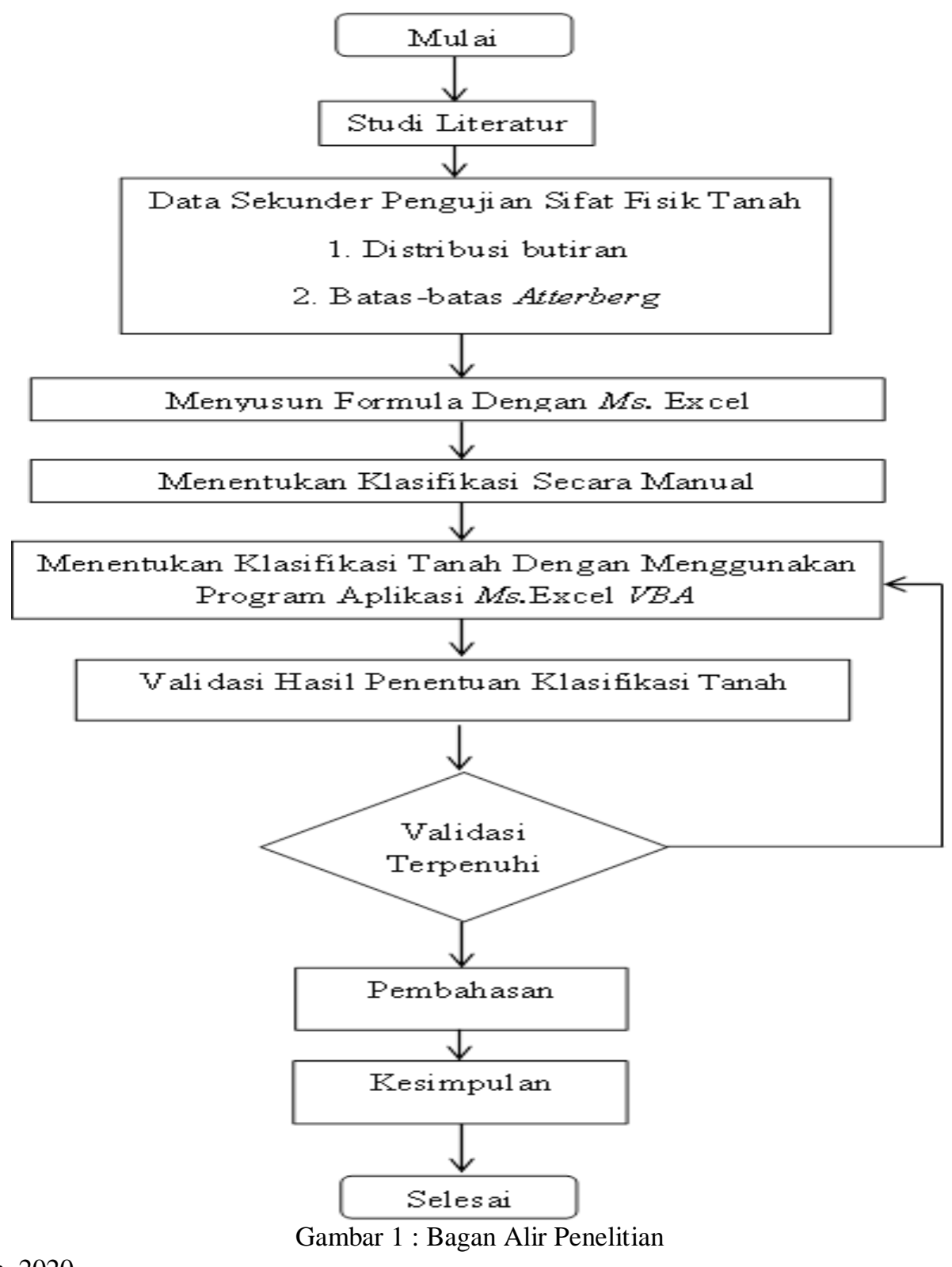

Sumber : Data Olahan, 2020

\section{HASIL DAN PEMBAHASAN \\ Klasifikasi Tanah Secara Manual}

Dalam pelaksanaan menentukan klasifikasi tanah dengan cara manual adalah sebagai berikut : 
Bertha Cahya Carolin et al., Penentuan Klasifikasi Tanah Sistem Uscs (Unified Soil Classification System) dengan Bantuan Ms Excel

1. Mengetahui nilai analisis butir tanah, tanah berbutir halus atau tanah berbutir kasar

Tabel 1 Data Hasil Pengujian Analisis Butir Tanah

\begin{tabular}{ccccccc} 
fraksi kasar/ halus & \multicolumn{3}{c}{ Berat Contoh Tanah Kering $=$} & \multicolumn{2}{c}{128 gram } \\
\hline \#saringan & $\begin{array}{c}\text { Diameter } \\
\text { Butir }(\mathrm{mm})\end{array}$ & $\begin{array}{c}\text { Berat } \\
\text { Tertahan }\end{array}$ & $\begin{array}{c}\text { Kumulatif } \\
\text { Tertahan }\end{array}$ & $\begin{array}{c}\text { Persentase } \\
\text { Tertahan (\%) }\end{array}$ & $\begin{array}{c}\text { Persentase } \\
\text { Lolos (\%) }\end{array}$ & ket. \\
\hline 2 in & 50,4 & 0 & 0,00 & 0,00 & 100 \\
1 in & 25,2 & 0 & 0,00 & 0,00 & 100,00 \\
$3 / 8$ in & 9,5 & 0 & 0,00 & 0,00 & 100,00 \\
No. 4 & 4,75 & 0,51 & 0,51 & 0,40 & 99,60 \\
No. 10 & 2 & 0,001 & 0,51 & 0,40 & 99,60 \\
No. 40 & 0,425 & 0,35 & 0,86 & 0,67 & 99,33 \\
No. 200 & 0,075 & 0,62 & 1,48 & 1,16 & 98,84 \\
\hline
\end{tabular}

Sumber : Data Olahan, 2020

2. Setelah mengetahui bahwa tanah adalah tanah berbutir halus maka langkah selanjutnya dengan memperhatikan nilai batas cair (liquid limit),

Tabel 2 Data Hasil Pengujian Batas-batas Atterberg

\begin{tabular}{|c|c|c|c|c|c|c|c|}
\hline \multicolumn{2}{|l|}{ Uraian } & \multicolumn{4}{|c|}{ Batas Cair (SNI 03-1967-1990) } & \multirow{2}{*}{\multicolumn{2}{|c|}{$\begin{array}{c}\text { Batas Plastis } \\
\text { (SNI 03-1966-1990) }\end{array}$}} \\
\hline 1. Banyaknya Pukulan & & 40 & 30 & 21 & 17 & & \\
\hline 2. Nomor Cawan & & DU & $\mathrm{NU}$ & Al & C & ER & $A C$ \\
\hline 3. Berat Cawan + Tanah Basah & (gr) & 12,52 & 13,41 & 14,28 & 15,31 & 12,16 & 12,10 \\
\hline 4. Berat Cawan + Tanah Kering & (gr) & 10,97 & 11,53 & 12,00 & 12,71 & 11,23 & 11,16 \\
\hline 5. Berat Air & (gr) & 1,55 & 1,88 & 2,28 & 2,60 & 0,93 & 0,94 \\
\hline 6. Berat Cawan & (gr) & 8,67 & 8,78 & 8,74 & 9,00 & 8,76 & 8,58 \\
\hline 7. Berat Tanah Kering & (gr) & 2,30 & 2,75 & 3,26 & 3,71 & 2,47 & 2,58 \\
\hline 8. Kadar Air & $(\%)$ & 67,39 & 68,36 & 69,94 & 70,08 & 37,65 & 36,43 \\
\hline
\end{tabular}

Sumber: Data Olahan, 2020

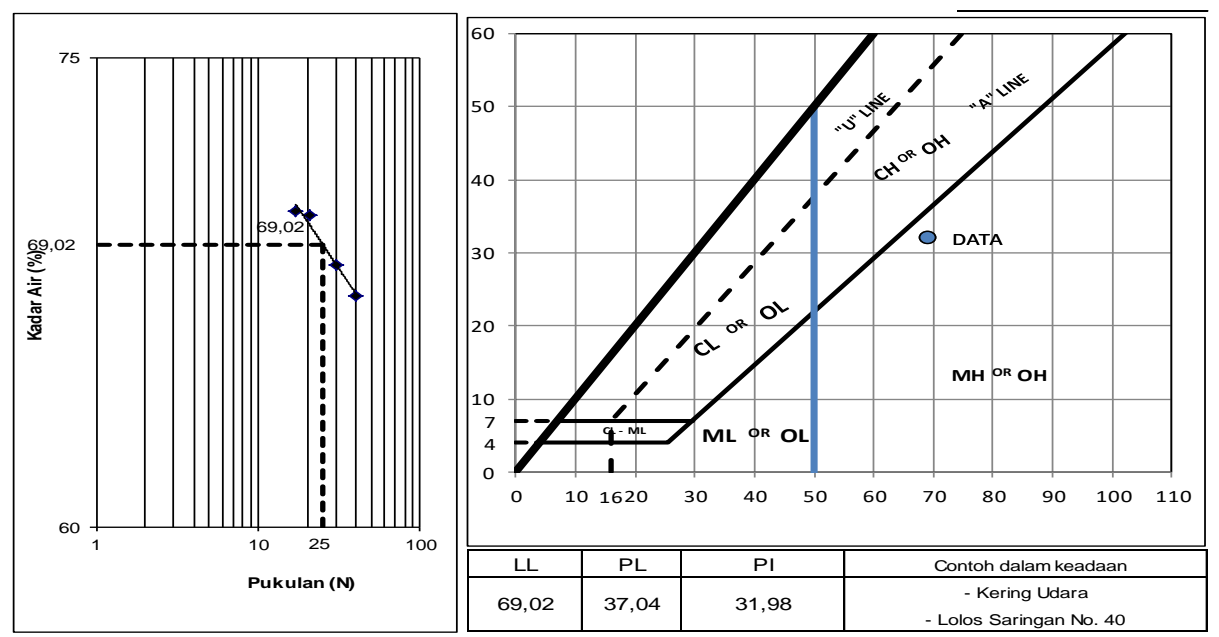

Sumber : Data Olahan, 2020

Gambar 2 Hasil Pengujian Batas-batas Atterberg

3. Setelah mengetahui nilai LL, maka dibutuhkan nilai indeks plastisitas (plasticity index). Dapat dilihat pada gambar 2 nilai plasticity index (PI) adalah 31,98\%, kurang dari $50 \%$.

4. Titik temu antara PI dan LL berada di bawah garis A.

5. Pada klasifikasi tanah sistem USCS terdapat ketentuan sebagai berikut :

a. apabila butir tanah tertahan saringan no.200 kurang dari $15 \%$ maka jenis tanah elastic silt

b. apabila butir tanah tertahan saringan no.200 kurang dari $30 \%, 15$ - $29 \%$, jika persentase pasir lebih banyak dari pada persentase kerikil maka jenis tanah elastic silt with sand. Sebaliknya jika persentase kerikil lebih banyak dari pada persentase pasir maka jenis tanah elastic silt with gravel. 
c. apabila butir tanah tertahan saringan no.200 lebih dari $30 \%$, jika persentase pasir lebih banyak $15 \%$ dari pada persentase kerikil maka jenis tanah sandy elastic silt. Sebaliknya jika persentase pasir lebih banyak dari pada persentase kerikil namun selisih diantaranya persentase kerikil lebih dari 15\% maka jenis tanah sandy elastic silt with gravel.

d. apabila butir tanah tertahan saringan no. 200 lebih dari $30 \%$, jika persentase kerikil lebih banyak $15 \%$ dari pada persentase pasir maka jenis tanah gravelly elastic silt. Sebaliknya jika persentase kerikil lebih banyak dari pada persentase pasir namun selisih diantaranya persentase pasir lebih dari 15\% maka jenis tanah gravelly elastic silt with sand.

Berdasarkan dari hasil yang diperoleh pada tabel 1 nilai butir tanah tertahan saringan no.200 adalah 1,16\% kurang dari $15 \%$. Maka jenis tanah adalah lanau dengan nama elastic silt dengan simbol tanah MH.

\section{Klasifikasi Tanah Menggunakan Ms. Excel VBA}

Dalam pelaksanaan menentukan klasifikasi tanah dengan bantuan $M s$. Excel sebagai berikut :

Saat membuka aplikasi Ms. Excel, maka akan muncul tampilan lembar kerja Ms. Excel seperti pada gambar 3

PENGUJIAN KONSISTENSI ATTERBERG
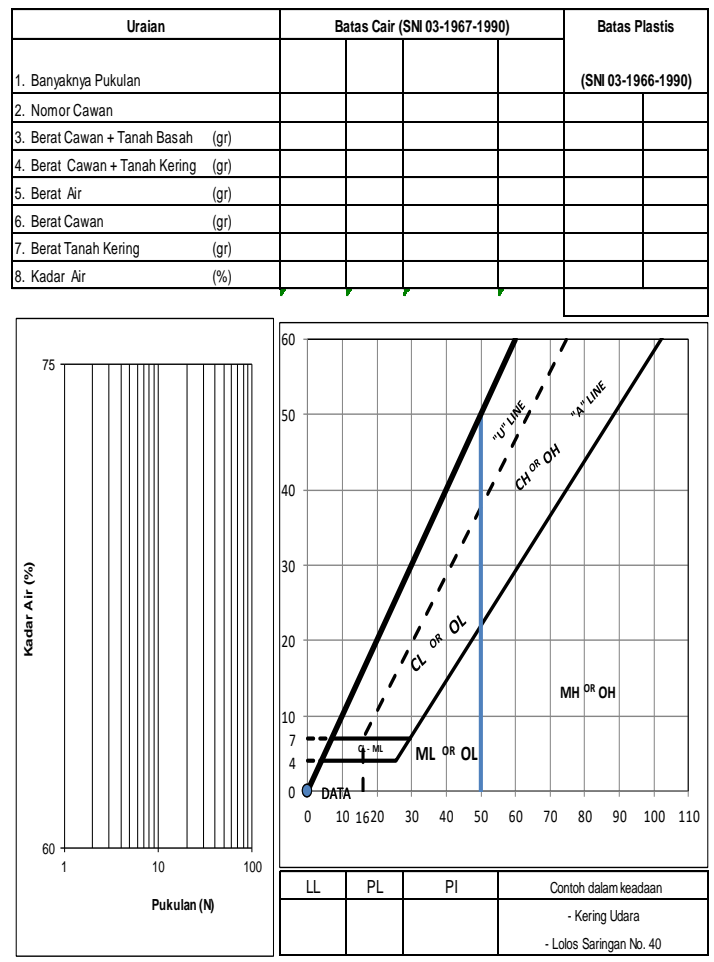

PENGUJIAN ANALISIS BUTIR

fraksi kasar/ halus
\begin{tabular}{|c|c|c|c|c|c|c|}
\hline \#saringan & $\begin{array}{c}\text { diameter } \\
\text { butir }(\mathrm{mm})\end{array}$ & $\begin{array}{c}\text { berat } \\
\text { tertahan }\end{array}$ & $\begin{array}{c}\text { kumulatif } \\
\text { tertahan }\end{array}$ & $\begin{array}{c}\text { Persentase } \\
\text { tertahan }(\%)\end{array}$ & $\begin{array}{c}\text { Persentase } \\
\text { lolos }(\%)\end{array}$ & ket. \\
\hline 2 in & 50,4 & & & & & \\
\hline 1in & 25,2 & & & & & \\
\hline $3 / 8$ in & 9,5 & & & & & \\
\hline No. 4 & 4,75 & & & & & \\
\hline No. 10 & 2 & & & & & \\
\hline No. 40 & 0,425 & & & & & \\
\hline No. 200 & 0,075 & & & & & \\
\hline
\end{tabular}

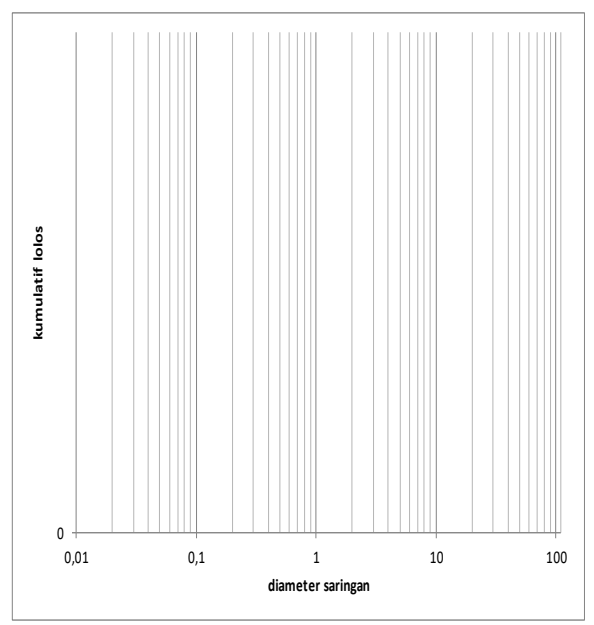

Sumber: Data Olahan, 2020

Gambar 3 Lembar Kerja Ms. Excel untuk data hasil pengujian tanah

\begin{tabular}{|c|c|c|c|c|c|c|c|}
\hline \multicolumn{6}{|c|}{ Sieve Analysis } & \multirow{3}{*}{\multicolumn{2}{|c|}{ Atterberg Limits }} \\
\hline No. Saringan & Satuan & Tertahan & Lolos & & & & \\
\hline $2 "$ & $\%$ & & & & & & \\
\hline 1" & $\%$ & & & Gravel & 0,00 & & \\
\hline $3 / 8^{\prime \prime}$ & $\%$ & & & Sand & 0,00 & $\mathrm{LL}$ & $\%$ \\
\hline No. 4 & $\%$ & & & & & $\mathrm{PL}$ & $\%$ \\
\hline No. 10 & $\%$ & & & $\mathrm{Cu}$ & & $\mathrm{PI}$ & $\%$ \\
\hline No. 40 & $\%$ & & & Cc & & & \\
\hline No. 200 & $\%$ & & & & & & \\
\hline
\end{tabular}

Open File

Klasifikasi Tanah

Eksekusi

Gambar 4 Rangkuman Hasil Pemeriksaan Pada Lembar Kerja Ms. Excel

Sumber: Data Olahan, 2020 
Bertha Cahya Carolin et al., Penentuan Klasifikasi Tanah Sistem Uscs (Unified Soil Classification System) dengan Bantuan Ms Excel

Pada gambar 3 tampilan lembar kerja Ms. Excel terdapat dua jenis pengujian. Kolom pada pengujian tersebut akan diisi dengan data hasil pengujian tanah.

1. Pada pengujian konsistensi atterberg data yang dibutuhkan terdiri dari :
a. Baris 1 adalah banyaknya pukulan.
b. Baris 2 adalah nomor cawan.
c. Baris 3 adalah Berat cawan + tanah basah.
d. Baris 4 adalah Berat cawan + tanah kering.
e. Baris 6 adalah Berat cawan kosong

2. Pada Pengujian analisis butir data yang dibutuhkan adalah berat tertahan pada tiap-tiap saringan, maka pada kolom yang perlu diisi dengan data hasil pengujian adalah kolom berat tertahan .

Rangkuman hasil pemeriksaan seperti yang terdapat pada gambar 4 adalah kesimpulan dari pengujian konsistensi atterberg dan analisis butir. Pada rangkuman hasil pemeriksaan terdapat dua tombol perintah, yaitu :

1. Open File untuk membuka hasil pengujian tanah apabila data hasil pengujian tanah berupa file.

2. Eksekusi, tombol perintah ini berisi modul untuk mengoperasikan Ms. Excel VBA dalam menentukan klasifikasi tanah berdasarkan sistem USCS (ASTM D 2487). Pada bahasa pemrograman yang digunakan adalah fungsi if then, if then else dan pernyataan select case.

Seperti dapat dilihat pada gambar 5

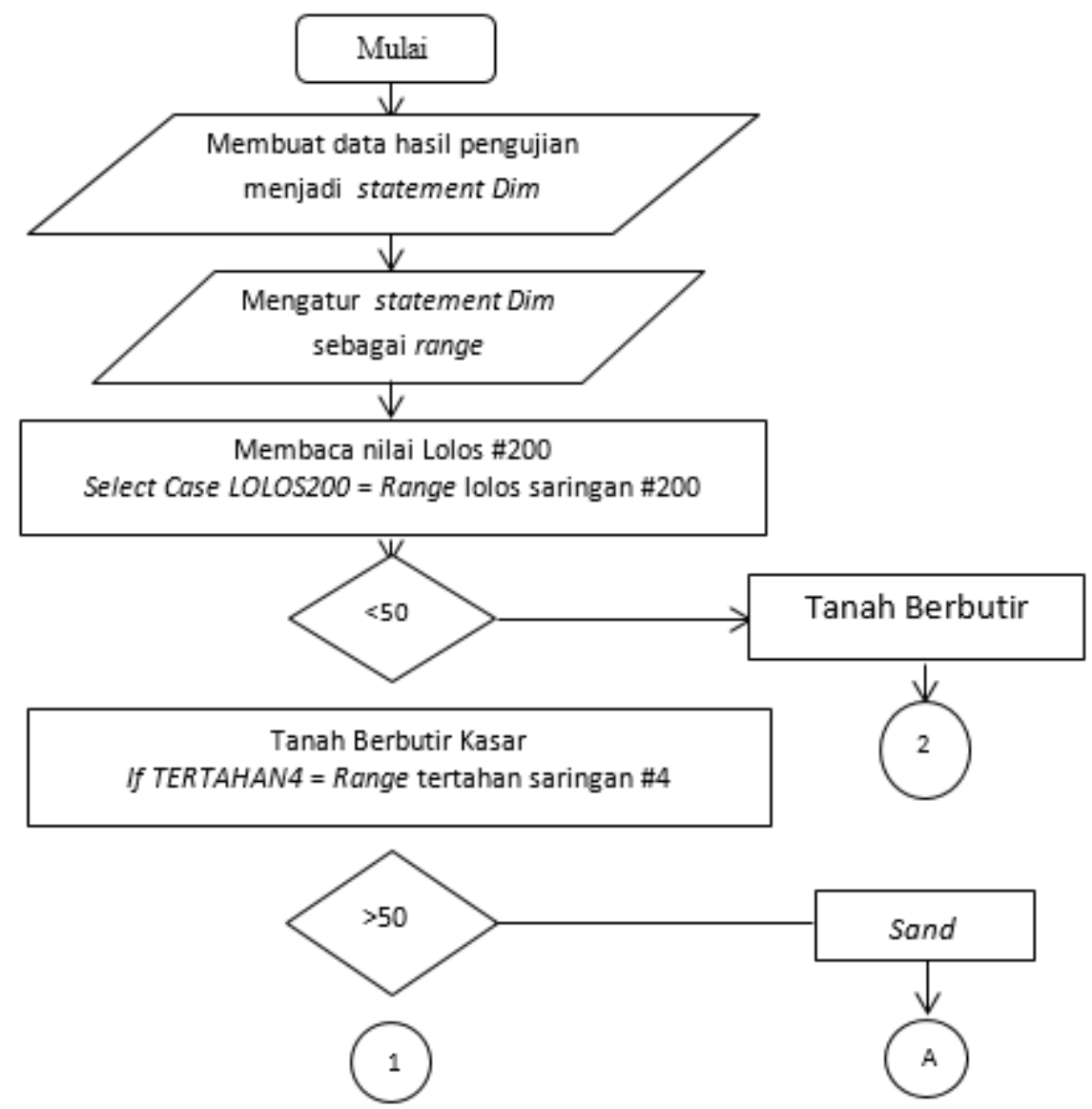


Bertha Cahya Carolin et al., Penentuan Klasifikasi Tanah Sistem Uscs (Unified Soil Classification System) dengan Bantuan Ms Excel

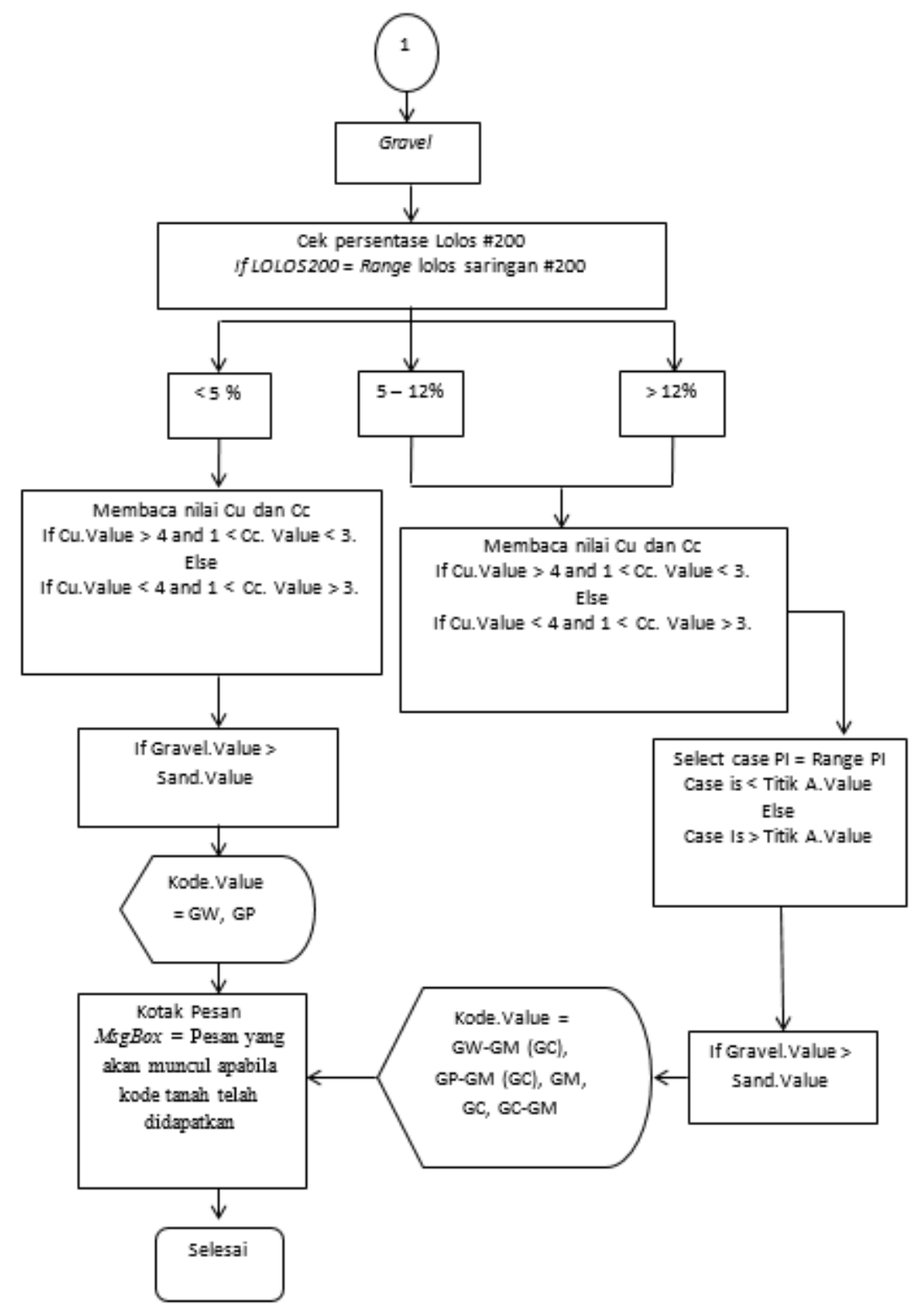


Bertha Cahya Carolin et al., Penentuan Klasifikasi Tanah Sistem Uscs (Unified Soil Classification System) dengan Bantuan Ms Excel

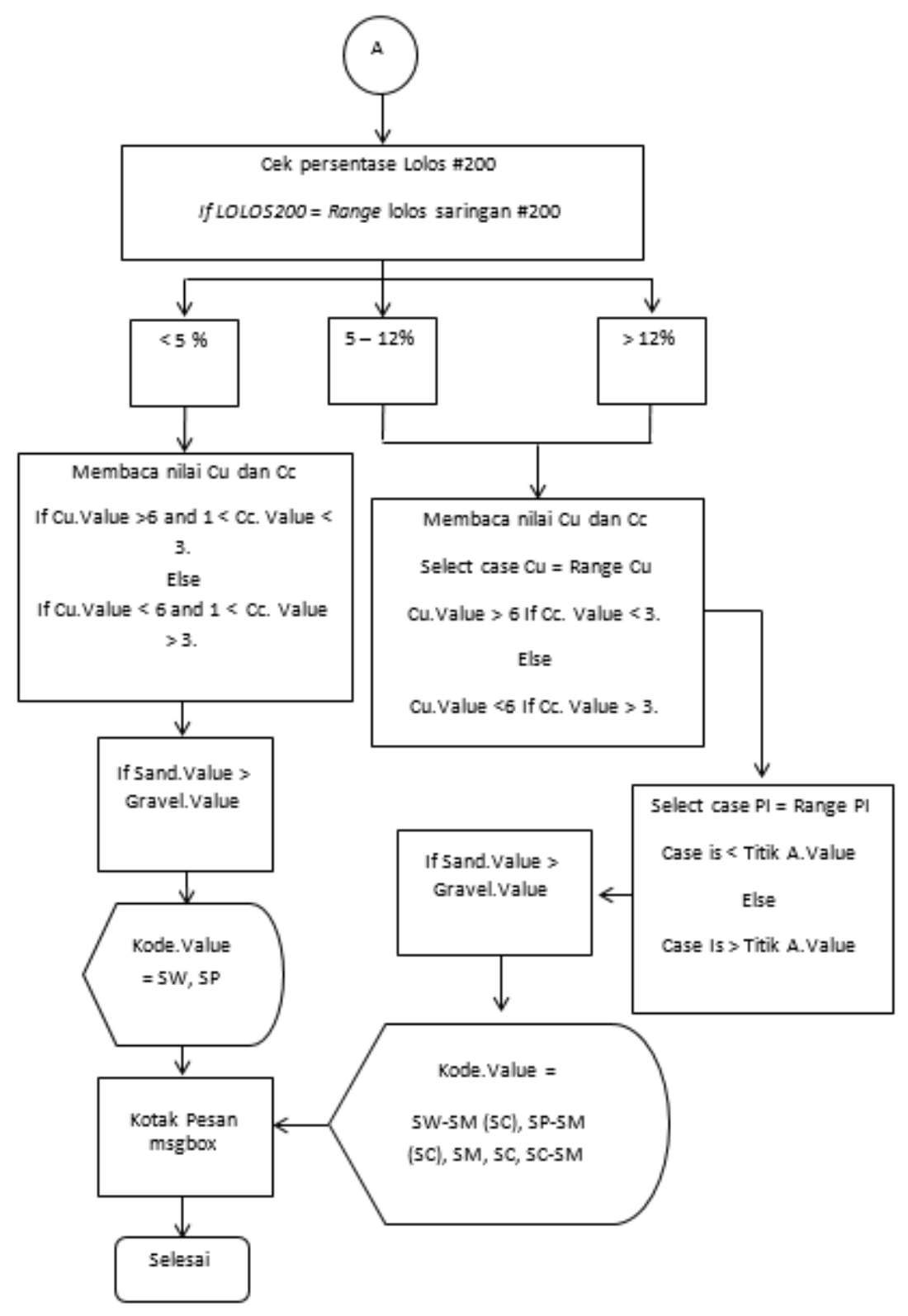




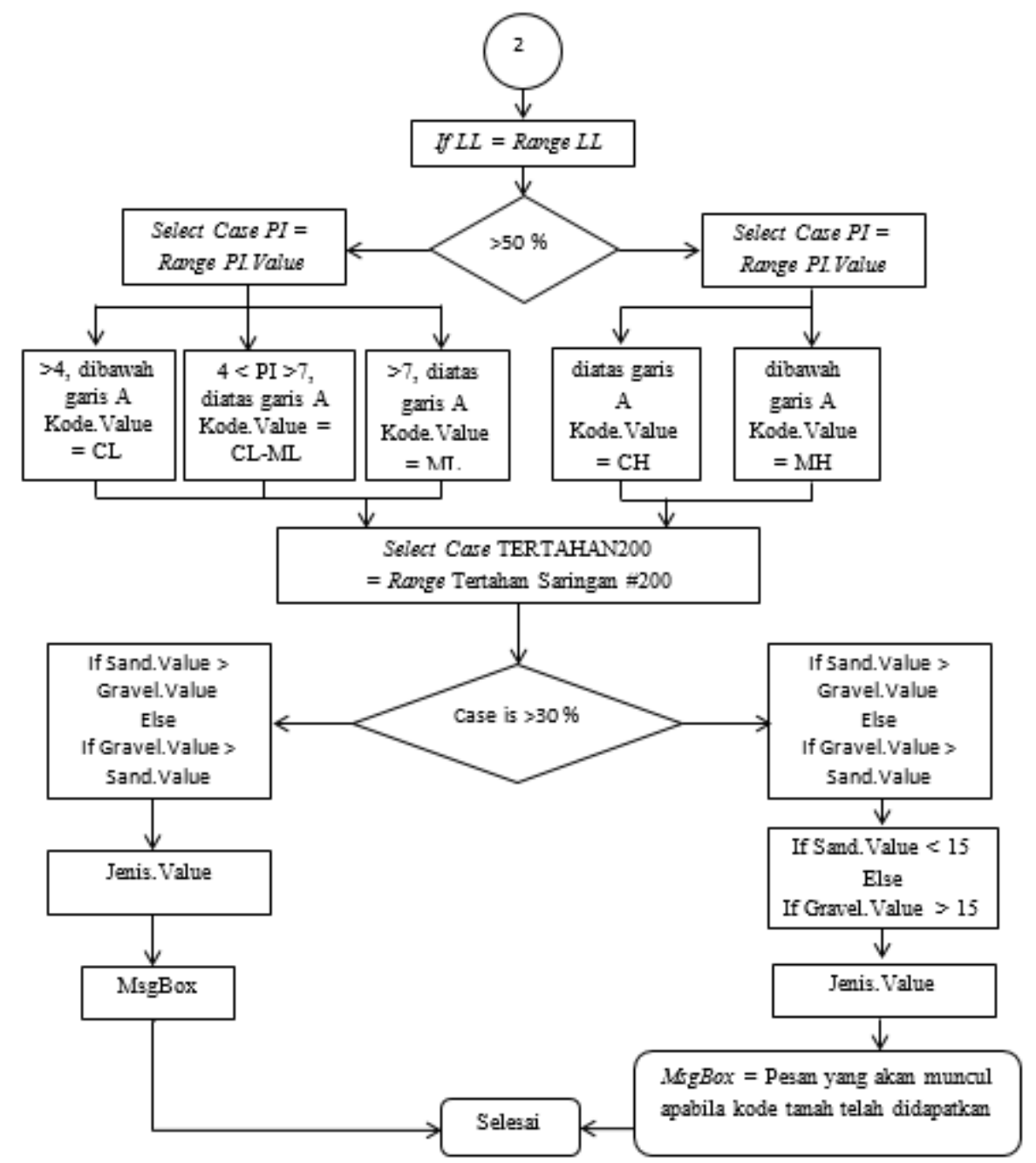

Gambar 5 Bagan Alir Klasifikasi Tanah Sistem USCS Pada Ms. Excel VBA

Sumber : Data Olahan, 2021

\section{PEMBAHASAN}

\section{Validasi dan Aplikasi Program}

Dari beberapa sampel pengujian sifat fisik tanah yang telah dilakukan di Laboratorium Teknik Universitas Batanghari dalam menentukan klasifikasi tanah dan telah diuji dengan program klasifikasi tanah ini, diperoleh hasil seperti pada tabel 3

Tabel 3 Hasil Pengujian Program Penentuan Klasifikasi Tanah

\begin{tabular}{cccc}
\hline Kode Tanah & Lokasi Sampel & Hasil Lab. Teknik & Hasil Program \\
\hline $\begin{array}{c}\text { Pembangunan Bank } \\
\text { Jambi BM.02 }\end{array}$ & Kota Jambi & MH & EH \\
Titik I H-31ke 32 & Mendahara, Tanjung Jabung Timur & OH & OH \\
BH-01 & Ruas jalan desa Danau Embat, Kab. Batanghari & Organic Silt & Organic Silt \\
Titik II G-20 & & Cl & CL \\
- G21 & Mendahara, Tanjung Jabung Timur & OH Clay & Sandy Lean Clay \\
OH & Organic Silt & Organic Silt \\
\hline Sumber:
\end{tabular}

Sumber: Data Olahan, 2021

Pada pengujian aplikasi Ms. Excel VBA yang telah dilakukan terhadap beberapa data hasil pengujian tanah, dapat diketahui bahwa penggunaan aplikasi Ms. Excel VBA untuk proses penentuan klasifikasi tanah sistem USCS memerlukan waktu yang lebih efisien apabila dibandingkan dengan proses secara manual. 


\section{SIMPULAN}

1. Menentukan klasifikasi tanah sistem USCS memerlukan data hasil pengujian konsistensi atterberg dan hasil pengujian analisis butir tanah. Menentukan klasifikasi tanah dengan cara manual yaitu memperhatikan hasil analisis butir tanah yaitu tanah berbutir kasar apabila persentase nilai tertahan saringan No. $200 \geq 50 \%$ selanjutnya Persentase nilai tertahan saringan No. $4 \geq 50 \%$ untuk simbol tanah G (gravel), untuk Persentase nilai tertahan saringan No. $4<50 \%$ untuk simbol tanah S (sand). Kemudian tanah berbutir halus apabila persentase nilai tertahan saringan No. $200<50 \%$. Jenis tanah C (clay) apabila titik pertemuan antara nilai LL dan PI berada di atas garis A pada plasticity chart. Dan untuk Jenis tanah M (silt) apabila titik pertemuan antara nilai LL dan PI berada di bawah garis A pada plasticity chart.

2. Program aplikasi Ms. Excel VBA dapat meningkatkan efesiensi waktu dalam menentukan klasifikasi tanah sistem USCS sehingga waktu yang dibutuhkan untuk menentukan klasifikasi tanah sistem USCS semakin singkat. Hasil dari program aplikasi Ms. Excel VBA untuk menentukan klasifikasi tanah valid berdasarkan ASTM D-2487 Sistem USCS, sehingga program ini layak untuk digunakan sebagai alat bantu menentukan klasifikasi tanah. Lembar kerja pada aplikasi Ms.Excel VBA berupa file yang dapat disimpan dan dicetak.

\section{DAFTAR PUSTAKA}

Arief, Furchan. 2004. Pengantar Penelitian Dalam Pendidikan. Yogyakarta : Pustaka Pelajar.

Arikunto, S. 2002. Metodologi Penelitian Suatu Pendekatan Proposal. Jakarta: PT. Rineka Cipta.

Bowles, Joseph E. Johan K. Helnim. 1991. Sifat Fisis Tanah dan Geoteknik Tanah (Mekanika Tanah). Jakarta: PT. Erlangga,

Hardiyatmo, H.C. 2012. Mekanika Tanah 1. Yogyakarta: Gadja Mada University Press.

Wicaksono, Yudhy. 2017. Panduan Lengkap Otomatisasi Pekerjaan Menggunakan Macro Excel. Jakarta : PT Elex Media Komputindo.

Winarno, Edy., Ali Zaki. 2014. Pemrograman VBA untuk Excel All Version. Jakarta : PT Elex Media Komputindo. 